\title{
Variation in antioxidant gene expression in the scleractinian coral Acropora millepora under laboratory thermal stress
}

\author{
N. B. M. Császár ${ }^{1,2}$, F. O. Seneca ${ }^{2,3}$, M. J. H. van Oppen $^{2, *}$ \\ ${ }^{1}$ Department of Environmental Sciences, Plant Functional Climate Change Cluster, University of Technology, Sydney, \\ PO Box 123, Broadway, Sydney, New South Wales 2007, Australia \\ ${ }^{2}$ Australian Institute of Marine Science, PMB No. 3, Townsville MC, Queensland 4810, Australia \\ ${ }^{3}$ Coral Genomics Group, James Cook University, Townsville, Queensland 4811, Australia
}

\begin{abstract}
The effects of climate change over the last few decades have pushed the majority of reef-building corals close to their upper thermal limit. Upon exposure to thermal stress, the intracellular formation of harmful oxygen intermediates can lead to the disruption of the obligate symbiosis between the coral host and their dinoflagellate endosymbionts (zooxanthellae), a process known as coral bleaching. Applications of molecular techniques to cnidarian research have recently enhanced our understanding of the magnitude of corals' transcriptional response to various stressors. In the present study, we developed a quantitative real-time polymerase chain reaction assay to assess expression levels of 4 genes involved in the corals' oxidative stress response ( $H S P 70, M n S O D$, ferritin, $\mathrm{Zn}^{2+}$-metalloprotease) after exposure to laboratory-controlled thermal stress. Using the IndoPacific reef coral Acropora millepora, our study provides the first population-scale analysis of antioxidant gene expression in coral. Despite the significant up-regulation of those 4 genes in the thermally stressed samples relative to non-stressed samples, our results show that there is an enormous intraas well as inter-colony variation in transcript abundance at a particular point in time. We discuss the potential roles of ferritin and $\mathrm{Zn}^{2+}$-metalloprotease in the break down of the intra-cellular $\mathrm{Fe}^{2+}$ homeostasis and in coral host cell detachment, respectively, during bleaching conditions. Our results emphasise the importance of measuring inter-individual variation to gain an insight into the population response to a common and increasingly encountered environmental stressor.
\end{abstract}

KEY WORDS: Oxidative stress · Gene expression • Variation · Coral bleaching · Acropora millepora • Real-time PCR · Magnetic beads

Resale or republication not permitted without written consent of the publisher

\section{INTRODUCTION}

Coral reefs are currently facing unprecedented pressures on a global scale, due to natural and anthropogenic stressors related to climate change (HoeghGuldberg 1999, Hughes et al. 2003). Elevated seawater temperature, often in combination with increased irradiance levels (Brown et al. 2000, Takahashi \& Murata 2008), has repeatedly been reported to disrupt the symbiosis between the coral and its dinoflagellate endosymbionts (Symbiodinium spp. or zooxanthellae), a process termed coral bleaching (Glynn 1996; reviewed by Hoegh-Guldberg 1999, Douglas 2003). Of utmost concern is thermally induced bleaching which might occur every 2 yr on most coral reefs by 2050 as a result of further increases in sea water temperatures (Donner et al. 2005). This dissociation of the coral-algal symbiosis is believed to be initiated by impaired photosynthesis of in hospite zooxanthellae (Warner et al. 1996, Jones et al. 1998, Warner et al. 1999). Although it is not entirely clear today whether the bleaching response is triggered by the dysfunction 
of zooxanthella photosystem II (PSII) through damage of its reaction centre protein D1 (Warner et al. 1999), or through impacts downstream of PSII (i.e. impairment of $\mathrm{CO}_{2}$ fixation enzymes; Jones et al. 1998), it is expected that either of these scenarios results in the net production of reactive oxygen species (ROS).

Besides their crucial role for many physiological functions, ROS such as superoxide radicals $\left(\mathrm{O}_{2}{ }^{-}\right)$, singlet oxygens $\left({ }^{1} \mathrm{O}_{2}\right)$, hydrogen peroxides $\left(\mathrm{H}_{2} \mathrm{O}_{2}\right)$ and hydroxyl radicals ( $\mathrm{HO}^{\circ}$ ) can disrupt vital biological functions via lipid peroxidation, protein oxidation and DNA degradation (reviewed by Dalton et al. 1999, Lesser 2006). ROS are produced in all aerobic organisms during regular cellular respiration, through the incomplete reduction of molecular oxygen to water (Fridovich 1998), and are normally in balance with antioxidant molecules (reviewed by Scandalios 2002). Typically, the maintenance of the cellular redox balance is provided by a host of enzymatic (e.g. superoxide dismutase [SOD], catalase, peroxidases) and nonenzymatic (e.g. gluthathione, tocopherol, carotenoids) antioxidants, due to their supply of the necessary reduction potential. However, organisms experience oxidative stress as soon as this critical balance is shifted towards a more oxidised state, either through antioxidant depletion or excess accumulation of ROS (Scandalios 2002).

Oxidative stress is routinely encountered by organisms exposed to changing environmental conditions, such as increases in temperature. Coral-algal associations, for example, are exposed to hyperoxia during daytime due to photosynthesis, while respiration of both the host and its symbionts leads to hypoxic conditions at night (D'Aoust et al. 1976, Richier et al. 2005). To counteract these deleterious hyperoxic effects, organisms have evolved adaptive responses induced by changing levels of ROS, leading to the activation or silencing of genes encoding for the various defensive antioxidants (Dalton et al. 1999). For example, in response to ROS production, genes encoding for SOD and the iron-binding protein ferritin (Torti \& Torti 2002) are transcribed and translated to bind and/or neutralise these reactive oxygen intermediates (Balla et al. 1992, Cairo et al. 1995, Gasch et al. 2000). In addition, molecular chaperones such as heat-shock proteins (HSPs) are rapidly synthesised (Benjamin \& McMillan 1998, Madamanchi et al. 2001) to prevent protein aggregation under stressful conditions (Gething \& Sambrook 1992).

From stress marker studies aimed at the level of proteins (e.g. Downs et al. 2000, 2002, Brown et al. 2002), it is known that corals, like other animal taxa, are capable of rapidly elevating cellular levels of HSPs and SODs in response to oxidative stress. At the transcriptional level (i.e. mRNA), however, the ability of corals to up- or down-regulate genes that code for antioxidants in response to thermal stress, as well as the transcriptional variation among and within individual corals remains largely unknown.

Pioneering studies directly targeting stress gene biomarkers identified and quantified mRNA transcript abundances in corals that were mainly exposed to various toxicants (Morgan et al. 2001, Morgan \& Snell 2002). Further progress in gene expression profiling (reviewed by Snell et al. 2003) has led to the development of the first coral complementary DNA (cDNA) microarray, a technique principally capable of assaying the expression of 1000s of genes simultaneously. In particular, these first studies confirmed a dynamically changing transcriptome in corals exposed to various environmental stressors such as temperature, salinity, sediment, low and high light (Edge et al. 2005), as well as heavy metals and organic pollutants (Morgan et al. 2005), using small gene number-microarrays holding 32 genes. A more recent study (Edge et al. 2008) showed that among these genes, all of which cover a range of biological functions, a sub-set of 12 genes displayed oscillating expression levels in a natural population of the Caribbean coral Montastraea faveolata over the course of 7 mo. Despite these important studies, however, we still have only a limited understanding of the transcriptional variation expected within a population of corals exposed to the same and most immediate environmental stressor related to climate warming, i.e. elevated temperature.

To address this issue, we performed a mRNA transcript study, comparing levels of stress-gene expression within and between 20 colonies of the widely abundant Indo-Pacific reef coral Acropora millepora exposed to thermal stress under low light levels in a controlled laboratory set-up. All corals contained only 1 dominant symbiont type belonging to Symbiodinium Clade D (sensu van Oppen et al. 2001; GenBank Accession EU024793). We developed a quantitative real-time polymerase chain reaction (qRT-PCR) assay based on expressed sequence tags (ESTs), short DNA fragments ( 200 to $500 \mathrm{bp}$ ) of expressed genes that showed significant up-regulation in fieldbleached samples of $A$. millepora during a previous pilot microarray experiment (Seneca et al. in press). From these numerous up-regulated ESTs, we chose 2 promising candidate genes, ferritin and a $\mathrm{Zn}^{2+}$-metalloprotease. Another 2 genes, HSP7O and MnSOD, were selected in addition, based on their well-known fundamental roles in restoring cellular homeostasis during oxidative stress (e.g. Fridovich 1998, Downs et al. 2002, Lesser 2006). Expression levels of these 4 genes were investigated both within and between thermally stressed coral colonies relative to nonstressed colonies. 


\section{MATERIALS AND METHODS}

Origin and treatment of corals. Fragments from each of 20 distinct colonies of the scleractinian coral Acropora millepora were collected from an inshore reef in the central Great Barrier Reef (Nelly Bay, Magnetic Island: $19^{\circ} 09.736^{\prime} \mathrm{S}, 146^{\circ} 51.331^{\prime} \mathrm{E}$ ) from 3 to $5 \mathrm{~m}$ depth using SCUBA, and immediately transferred to shaded $(50 \%)$ outdoor aquariums at the Australian Institute of Marine Science (AIMS, Townsville) in late August 2006. Ambient water temperatures at Nelly Bay were around $23^{\circ} \mathrm{C}$ at that time of the year. In order to ensure the functioning of the temperature-control unit during the subsequent heat-stress experiment by reducing the temperature gap between control and treatment temperatures (outlined further below), the corals held in the outdoor aquariums were slowly acclimated to $27^{\circ} \mathrm{C}$ over a period of $2 \mathrm{wk}$.

In order to test for genetic distinctiveness among the investigated coral colonies, microsatellite genotyping at loci Amil2_12, Amil2_22 and Amil2_23 (van Oppen et al. 2006) was conducted. This confirmed a unique multi-locus genotype for each of the investigated colonies (data not shown).

Identification of in hospite symbionts at the subcladal level was accomplished by analysing sequences of the nuclear ribosomal DNA internal transcribed spacer 1 (rDNA ITS1) using a modified protocol of van Oppen et al. (2001) with the single-strand conformational polymorphism (SSCP) method (Orita et al. 1989, Sunnucks et al. 2000). PCR products ( $700 \mathrm{bp}$ length) were diluted (1 in 4 parts) in SSCP loading buffer, denatured for $5 \mathrm{~min}$ at $95^{\circ} \mathrm{C}$, and snap-cooled on ice to allow the separated DNA strands to fold back onto themselves. One microlitre of sample was then loaded onto $20 \mathrm{~cm}$ long, $4 \%$ non-denaturing polyacrylamide gels, together with reference ITS1 DNA templates from Symbiodinium (sub-) clades C1, C2 and a D sub-clade common in GBR corals (GenBank Accession Numbers-C1: AF380551, C2: AY643495, C2*: AY643497, D: EU024793). Gels were run at $22^{\circ} \mathrm{C}$ and $1200 \mathrm{~V}$ for $45 \mathrm{~min}$ on a Gel-Scan 2000 (Corbette Research). All Acropora millepora colonies harboured exclusively clade D Symbiodinium, with no signs of any background zooxanthella populations of other symbiont types (data not shown).

For the analysis, a total of 160 (8 from each of 20 colonies) coral nubbins (i.e. branches), consisting of 4 pairs of 2 immediately adjacent nubbins from each of the 20 colonies, were brought into indoor tanks and arranged in a randomised block design. This set-up resulted in 4 replicate tanks with every colony being represented by a pair of adjacent clonal nubbins per tank (i.e. a total of 40 nubbins per tank, 2 from each of 20 genotypes).
These pairs of immediately adjacent nubbins of the same colony were chosen for comparative gene expression analysis in a controlled laboratory set-up based on the assumption that they do not only share an identical genotype, but were also exposed to a similar micro-climate in the field. Thus, due to their shared similar developmental history, immediately neighbouring nubbins within the same coral colony should resemble each other physiologically more than more distant parts of the same colony.

Lights were mounted above each of the 4 tanks and provided an average underwater light intensity of $130 \pm 10 \mu \mathrm{mol}$ photons $\mathrm{m}^{-2} \mathrm{~s}^{-1}$ on a $10 \mathrm{~h}$ light: $14 \mathrm{~h}$ dark cycle $(10 \times 400 \mathrm{~W}$ metal halide lamps, BLV). The lights were UV filtered in order to avoid radiation-induced bleaching (Gleason \& Wellington 1993) and to measure the response to thermal stress only. Tanks were supplied with fresh filtered $(1 \mu \mathrm{m})$ seawater, which was held at $27^{\circ} \mathrm{C}\left( \pm 0.1^{\circ} \mathrm{C}\right)$ via computer control using a flow-through system at a rate of $1.21 \mathrm{~min}^{-1}$.

Corals were given an acclimation period of $2 \mathrm{wk}$ to the indoor aquarium conditions prior to separating the pairs of nubbins and instantly snap-freezing one of them in liquid nitrogen. The removed and frozen nubbins served as the baseline treatment $\left(27^{\circ} \mathrm{C}\right.$, nonbleaching samples, $\mathrm{n}=80$ ) for the post-experimental gene expression analysis. The remaining individual nubbins from each of the 20 colonies were ramped up to $32^{\circ} \mathrm{C}$ over a period of $6 \mathrm{~d}$, after which they were held at that target temperature $\left( \pm 0.1^{\circ} \mathrm{C}\right)$ via computer control. Throughout the period of exposure to $32^{\circ} \mathrm{C}(9 \mathrm{~d})$, overall levels of bleaching and coral health were assessed visually by categorising samples into healthy (unbleached), slightly bleached, moderately bleached, severely bleached and dead.

Once all samples were moderately bleached, the experiment was terminated by snap-freezing this remaining set of nubbins $(n=80)$, which served as the bleaching treatment $\left(32^{\circ} \mathrm{C}\right)$. Sampling of these 2 different time points was performed at the same time of the day, starting after exposure to light for $3 \mathrm{~h}$, to ensure that the coral samples experienced no differences in light history prior to snap-freezing.

Extraction of mRNA and cDNA synthesis. The isolation technique used here (Dynabeads ${ }^{\circledR}$ Oligo $(\mathrm{dT})_{25}$, Invitrogen) has already been successfully applied to various plant and animal tissues (see manufacturer's instructions) and relies on base pairing between the eukaryotic mRNA's polyA tail and short sequences of oligo-dT covalently bound to the surface of magnetic beads. The procedure yields up to $20 \mathrm{ng} \mathrm{\mu l}^{-1}$ of pure and intact mRNA obtained from approximately 100 to $150 \mathrm{mg}$ of crude extract of crushed coral. It is important to note, however, that the following protocol is most 
likely not generally applicable to all scleractinian corals in this form and will have to be individually optimised for different species.

The following procedure outlines a slightly modified protocol from the manufacturer's instructions. Here, $200 \mu \mathrm{l}$ of Dynabeads Oligo(dT) ${ }_{25}$ solution was transferred to an RNAse-free, $1.5 \mathrm{ml}$ tube. After removing the storage solution using a MagnaRack Magnetic Separator (Invitrogen), the magnetic beads held back by the magnet were then washed in an equal volume of lysis/binding buffer $(100 \mathrm{mM}$ Tris- $\mathrm{HCl}, \mathrm{pH}$ 7.5; $500 \mathrm{mM} \mathrm{LiCl} ; 10$ mM EDTA, pH 8; $1 \%$ lithium dodecyl sulphate [LiDS]; $5 \mathrm{mM}$ dithiothreitol) until required. Meanwhile, coral nubbins were ground in stainless steel pestle and mortar, pre-chilled with liquid nitrogen, and a small spatula ( 100 to $150 \mathrm{mg}$ ) of the frozen crude powder was added to $400 \mu \mathrm{l}$ of the lysis/binding buffer. The sample lysate was vortexed at $9000 \mathrm{rpm}$ for $2 \mathrm{~min}$, and then spun down at $12000 \times g$ for $1 \mathrm{~min}$. The supernatant was then transferred to the tube containing the beads after discarding the lysis/ binding buffer. To allow annealing of the mRNAs' polyA tails to the bead-bound oligo-dTs, the combined bead-sample lysate was vortexed at $900 \mathrm{rpm}$ for $5 \mathrm{~min}$. The tube with the now hybridised bead-sample lysate was placed on the MagnaRack for 2 min, after which the supernatant was carefully discarded by pipetting. The bead-bound mRNA was then washed twice in $1 \mathrm{ml}$ of Washing Buffer A (10 mM Tris- $\mathrm{HCl}, \mathrm{pH} 7.5 ; 0.15 \mathrm{M}$ $\mathrm{LiCl}_{i} 1 \mathrm{mM}$ EDTA; $0.1 \%$ LiDS) and $0.5 \mathrm{ml}$ Washing Buffer B (10 mM Tris-HCl, pH 7.5; $0.15 \mathrm{M} \mathrm{LiCl}_{i} 1 \mathrm{mM}$ EDTA). Messenger RNA was finally eluted on the MagnaRack after re-suspension of beads in $25 \mu \mathrm{l}$ of ice-cold $10 \mathrm{mM}$ Tris $\mathrm{HCl}(\mathrm{pH} 7.5)$ and incubation at $80^{\circ} \mathrm{C}$ for $2 \mathrm{~min}$.

We tested mRNA for genomic DNA contamination from both the coral host and zooxanthellae. Using primers spanning an intron for a coral universal stress protein gene (USP7-GenBank Accession No. DY584810) in a conventional endpoint PCR confirmed that there was no contamination stemming from coral genomic DNA (data not shown). Likewise, using zooxanthella Clade D-specific primers for an actin-coding gene (GenBank Accession No. EU312078-80) (Mieog et al. 2009) on the pooled coral mRNA samples also tested negative for contamination stemming from zooxanthellar genomic DNA (data not shown). This, and the fact that the internal control genes (ICG) had very similar $C_{\mathrm{t}}$ values when normalised to total mRNA (see below), indicates that contamination with zooxanthellar mRNA was also negligible.

Integrity of mRNA was measured at $260 \mathrm{~nm}$ using an ND-1000 spectrophotometer (NanoDrop Technologies) with ratios of $260 \mathrm{~nm}: 280 \mathrm{~nm}$ between 1.8 and 2 as the criterion. Normalisation of mRNA quantities for the subsequent complementary DNA (cDNA) construction was again accomplished by measuring the absorbance at $260 \mathrm{~nm}$ on the ND-1000 spectrophotometer. Since the extraction technique yielded already pure mRNA, equal amounts of mRNA could be directly employed for each reverse transcription reaction. cDNA was constructed from mRNA on a Mastercycler personal (Eppendorf) using SuperScript III First-Strand Synthesis SuperMix (Invitrogen) according to the manufacturer's protocol. All control and treated cDNA samples $(20 \mu \mathrm{l})$ contained $1.64 \mathrm{ng} \mathrm{hl}^{-1}$ reversely transcribed mRNA. cDNA samples were stored at $-20^{\circ} \mathrm{C}$ until use in the qRT-PCR assay. qRT-PCR test trials confirmed that, in this case, normalising to total mRNA concentration exclusively, rather than to cDNA concentration, resulted in less experimental noise and produced more realistic estimates of true gene expression levels (data not shown).

qRT-PCR analysis. A total of 4 genes of interest (GOI) were chosen based on a combination of their known general role in the oxidative stress response (i.e. HSP7O and MnSOD; GenBank Accession Nos. DY585921 and DY581262, respectively) (Fridovich 1998, Downs et al. 2002, Lesser 2006), and on their previously mentioned significant up-regulation in a recent pilot cDNA microarray experiment on a field-bleached population of Acropora millepora (i.e. ferritin and a $\mathrm{Zn}^{2+}$-metalloprotease; GenBank Accession Nos. DY584495 and DY581364, respectively) (Seneca et al. in press).

The internal control genes (ICG) Ctg 1913 (GenBank Accession No. DY585358) and RiboL9 (GenBank Accession No. DY586572) are derived from ESTs that did not show a significant change in gene expression between treatments in the already mentioned pilot microarray experiment (Seneca et al. in press). For the Acropora millepora population used in this assay, these 2 control genes were preferred as references over GAPDH and other candidate ICGs due to their highly stable expression rates between treatments during test trials.

Specific forward and reverse primers for both GOI and ICG were designed (90 to $110 \mathrm{bp}$ amplicon length, $\sim 55 \% \mathrm{GC}$ content, $65^{\circ} \mathrm{C}$ primer $T_{\mathrm{m}}$ ) using the Custom Primers - OligoPerfect Designer software (Invitrogen) and were commercially obtained from Sigma-Aldrich. Sequences, as well as GenBank accession numbers for both GOI and ICG, are given in Table 1. Primer efficiencies were determined using standard curve analysis with a 5 -fold dilution series $(1 / 1,1 / 2,1 / 5,1 / 10,1 / 20)$ of pooled cDNA (Bustin 2004) from both control and treated samples (data not shown), and ranged from 1.77 to 2 .

Each cDNA sample was diluted 3-fold with UVsterilised Milli-Q water (60 $\mu$ l final volume), and $2 \mu \mathrm{l}$ 
Table 1. Forward (F) and reverse (R) primers used in the quantitative real-time polymerase chain reaction assay to amplify 4 oxidative stress genes in the coral Acropora millepora. Sequences and GenBank accession numbers for genes of interest and internal control genes (ICG) are also shown (ICGs are indicated with asterisks)

\begin{tabular}{|c|c|c|}
\hline Gene & GenBank & Primer sequence \\
\hline Ferritin & DY584495 & $\begin{array}{l}\text { (F) GCTCATTGCCCTTCACACGA } \\
\text { (R) AGGGAGGGCACCCATTTAGG }\end{array}$ \\
\hline HSP7O & DY585921 & $\begin{array}{l}\text { (F) TGCTGCGTTCACCTTCAAACA } \\
\text { (R) GCAACACAACAATTCCCACGA }\end{array}$ \\
\hline$M n S O D$ & DY581262 & $\begin{array}{l}\text { (F) CGATGCCTTGAAACCTGCAA } \\
\text { (R) TTTCTCTTCGGCCGCGTTAAG }\end{array}$ \\
\hline $\begin{array}{l}\mathrm{Zn}^{2+} \text {-metallo- } \\
\text { protease }\end{array}$ & DY581364 & $\begin{array}{l}\text { (F) TGCTGGCAGAAAATCCGACA } \\
\text { (R) CCСTCCTCTTTCCACTTGTCTCC }\end{array}$ \\
\hline Ctg $1913^{*}$ & DY585358 & $\begin{array}{l}\text { (F) GTGCGTGCTGTCCATATTAC } \\
\text { (R) TGAAGTCGTGGTCGTAGTTG }\end{array}$ \\
\hline RiboL9* & DY586572 & $\begin{array}{l}\text { (F) CTGAGAATGGCACATTGGTG } \\
\text { (R) ACACCTGAATTCGCACAGGT }\end{array}$ \\
\hline
\end{tabular}

comparisons in which equal variances were not assumed. For the 1-way ANOVA, colonies were factors and the percent of up- or down-regulation of genes was the dependent variable $(\alpha=0.05)$. Since all cDNA samples (control and bleached) were normalised to the same amount of mRNA template (see above), the actual $C_{\mathrm{t}}$ value of the control samples was used as a proxy to test for consistency of GOI expression within colonies and among replicates under non-bleaching conditions $\left(27^{\circ} \mathrm{C}\right)$ using a 1-way ANOVA $(\alpha=0.05)$. All analyses were performed using SPSS v. 14.0.

\section{RESULTS}

of diluted cDNA was used in triplicate $20 \mu \mathrm{l}$ qRT-PCR reactions with $1 \mu \mathrm{l}(4 \mu \mathrm{M})$ primers, $6 \mu \mathrm{l}$ UV-sterilised Milli-Q water and $10 \mu \mathrm{l}$ SYBR GreenER qPCR SuperMix Universal on a Rotor-Gene RG-3000A (Corbett Research). The conditions consisted of an incubation period at $50^{\circ} \mathrm{C}$ for 2 min followed by a holding step at $95^{\circ} \mathrm{C}$ for $10 \mathrm{~min}$. Cycling parameters included 40 cycles of $95^{\circ} \mathrm{C}$ for $15 \mathrm{~s}$ and $60^{\circ} \mathrm{C}$ for $60 \mathrm{~s}$, with data collection during each cycle after the $60^{\circ} \mathrm{C}$ step. Melting curve analysis to detect primer dimers was performed at the end of the $\mathrm{PCR}$ reaction with a ramp from 60 to $90^{\circ} \mathrm{C}$ at a rate of $0.1^{\circ} \mathrm{C} \mathrm{s}^{-1}$. No-template controls (NTCs) were frequently performed on separate runs throughout the entire analysis to ensure that primers, as well as the qRT-PCR master mix, contained no contaminants.

Threshold cycle differences $\left(\Delta C_{t}\right)$ were obtained by manually positioning the threshold immediately above the background noise in the exponential amplification phase. Fold-changes in gene expression were expressed as percent increment/decrement (e.g. 1.5-fold upregulation $=50 \%$ increment). The efficiency-corrected relative expression of each of the 4 GOIs in relation to the geometric mean of the 2 ICGs was calculated using geNorm software (Vandesompele et al. 2002).

Statistical analysis. Statistical significance of ICG normalised fold-changes between bleaching and nonbleaching treatments was assessed for each of the 4 GOIs at the $\Delta C_{\mathrm{t}}$ level using a 2-tailed $t$-test $(\alpha=$ 0.05 ). Within- and between-colony variation in gene expression was assessed using 1-way ANOVA at the 0.05 significance level. Levene's test for homogeneity of variances was used to determine whether compared colonies $(n=20)$ exhibited similar variances. Tamhane's T2 post-hoc test was applied to multiple
All clonal replicates $(\mathrm{n}=4$ ) of the 20 coral colonies of Acropora millepora investigated were similarly and moderately bleached at the end of the heat-stress experiment, and their gene expression profile was assessed relative to their non-bleached clonal counterparts. One coral nubbin from Colony 2 apparently died during exposure to $32^{\circ} \mathrm{C}$ as it did not display any gene expression at all. Therefore, the number of replicates for this colony was reduced to 3 . Overall, each of the 4 stress-induced genes showed a significantly higher transcript abundance in the bleaching relative to the non-bleaching treatment (between 9 and $24 \%$ upregulation; see Table 2), suggesting the induction of an antioxidant defence in the former. The variation in the direction and amplitude of expression change of these genes both within and between the coral colonies, however, was enormous (Fig. 1).

Table 2. Acropora millepora. Correlation coefficients (r) for the direction of gene expression change between the 4 genes across the bleached samples $(\mathrm{n}=79)$; positive correlations are indicated with asterisks. ${ }^{*}$ : significant, $\mathrm{p}<0.05$; $^{* *}$ : highly significant, $\mathrm{p}<0.01$. Mean levels and standard errors of antioxidant gene up-regulation in the bleached $(n=79)$ relative to the non-bleached $(\mathrm{n}=79)$ coral samples is given in percent $(\%)$ increment averaged over 20 colonies. Up-regulation was significant for each of the 4 genes $(\mathrm{p} \leq 0.01$, df $=78,2$-tailed $t$-test). $\mathrm{Zn}^{2+}$-met: $\mathrm{Zn}^{2+}$-metalloprotease

\begin{tabular}{|lllll|}
\hline \multirow{2}{*}{ Gene } & \multicolumn{3}{c}{ Correlation $(\mathrm{r})$} & \multirow{2}{*}{ Mean \pm SE } \\
& HSP70 & MnSOD & $\mathrm{Zn}^{2+}$-met & $(\%)$ \\
\hline Ferritin & $0.303^{* *}$ & 0.144 & $0.423^{* *}$ & $24.09 \pm 28$ \\
HSP70 & & $0.489^{* *}$ & $0.595^{* *}$ & $12.23 \pm 20$ \\
MnSOD & & & $0.278^{*}$ & $19.59 \pm 21$ \\
$\mathrm{Zn}^{2+}$-met & & & & $8.99 \pm 18$ \\
\hline
\end{tabular}



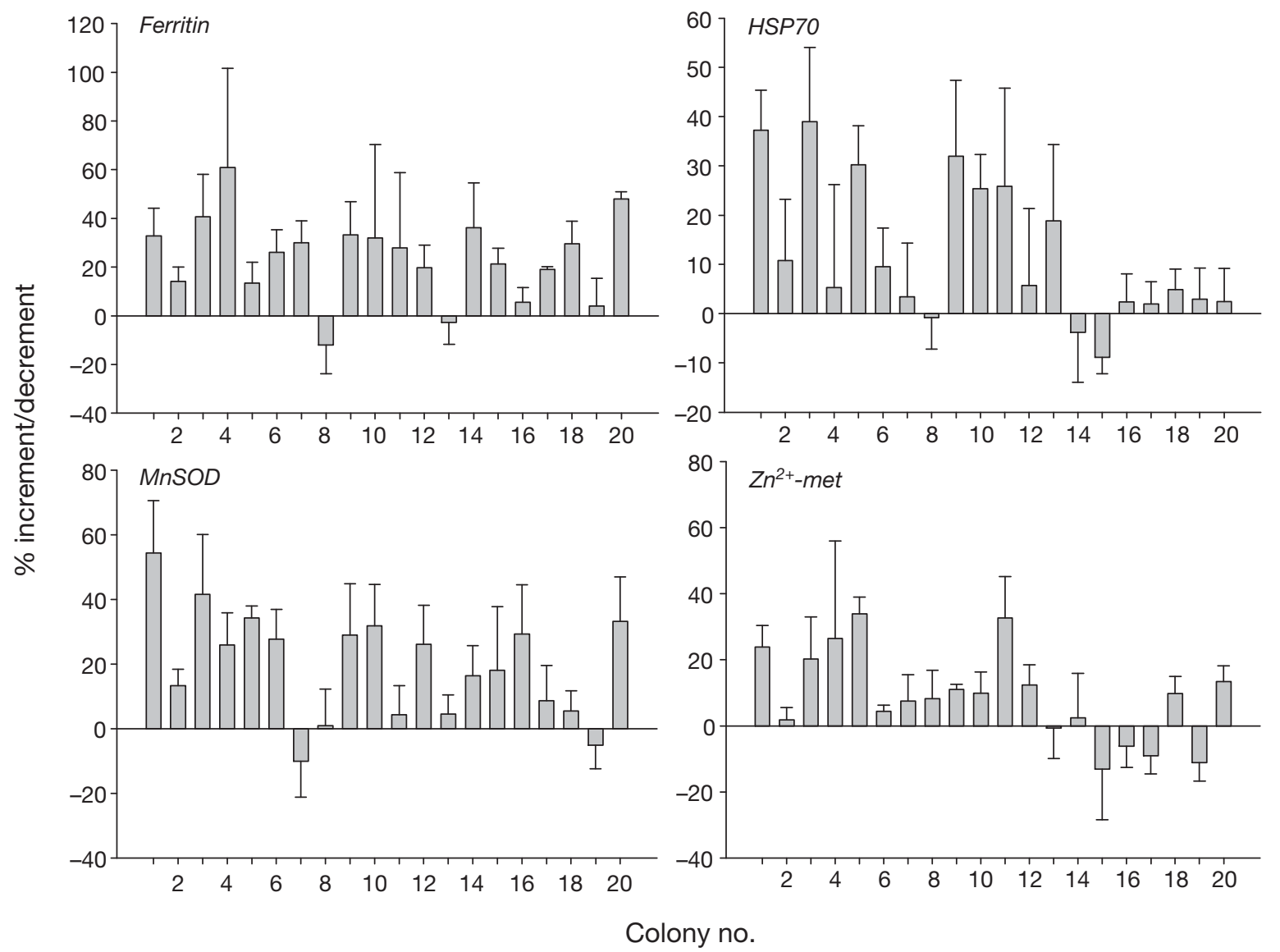

Fig. 1. Acropora millepora. Mean changes in gene expression levels of ferritin, HSP70, MnSOD and $\mathrm{Zn}^{2+}$-metalloprotease $\left(\mathrm{Zn}^{2+}\right.$ met) in each of 20 bleached colonies (arranged in ascending order on the $x$-axis) given in percent (\%) increment/decrement. Error bars represent standard errors $(\mathrm{n}=4$, except for Colony 2, for which $\mathrm{n}=3$ ). Note the different scales of the $y$-axis

Ferritin, the main intra-cellular iron-storage protein, was significantly up-regulated in bleached relative to control samples $(\mathrm{p}<0.001$, df $=78$, 2-tailed $t$-test), and showed the highest overall increment in transcript abundance $(24.1 \pm 28 \%)$ of all 4 genes (Table 2). In Fig. 1, it can be seen that ferritin was up-regulated in all except for 2 colonies (Colonies 8 and 13). The highest individual up-regulations were also observed for ferritin, as indicated by the high intra-colonial standard errors from Table 2. Colony 4, for example, displayed the highest average upregulation $(60.9 \pm 41 \%, \mathrm{n}=4)$ of ferritin; however, the intra-colony variation across its clonal replicates ranged from being up-regulated by almost $150 \%$, over being more or less unchanged to being downregulated by $\sim 15 \%$.

Second highest in overall up-regulation ( $\mathrm{p}<0.001$, $\mathrm{df}=78,2$-tailed $t$-test) was the gene for the antioxidant enzyme MnSOD (19.6 $\pm 21 \%)$. Again, only 2 colonies, Colonies 7 and 19, showed a lower average abundance in $M n S O D$ transcript in the bleached relative to the non-bleached samples.
The molecular chaperone gene HSP7O showed an overall transcript increment of $12.2 \pm 20 \%$ ( $p<0.001$, $\mathrm{df}=78,2$-tailed $t$-test), roughly half the expression rate of ferritin. Colonies 8, 14 and 15 showed an average down-regulation of $H S P 70$ transcripts.

Expression levels of $\mathrm{Zn}^{2+}$-metalloprotease, although on average increased by only $8.99 \pm 18 \%$ in the bleached samples, were also significantly higher $(\mathrm{p}=$ $0.01, \mathrm{df}=78,2$-tailed $t$-test) relative to the control treatment. Five of the 20 bleached colonies displayed lower levels of gene expression for this protease (i.e. Colonies 13, 15, 16, 17 and 19).

An isochronic average up-regulation of all 4 antioxidant genes occurred in 12 of the 20 coral colonies (Table 2). Four colonies showed lower levels of transcript abundance for 1 of the 4 genes, while at the same time being up-regulated for the remaining. While Colonies 7 and 14 were down-regulated for MnSOD $(10.06 \pm 11 \%, \mathrm{n}=4)$ and HSP7O $(3.81 \pm 10 \%, \mathrm{n}=4)$, both Colonies 16 and 17 were down-regulated for $\mathrm{Zn}^{2+}$-metalloprotease by $6.12 \pm 6.4 \%(\mathrm{n}=4)$ and $9.1 \pm$ $5.5 \%(\mathrm{n}=4)$, respectively. 
Another 4 colonies were, on average, down-regulated for 2 of the 4 genes at the same time. Colony 8 displayed down-regulation of ferritin $(12.04 \pm 12 \%, \mathrm{n}=$ 4) and $H S P 70(0.8 \pm 6.4 \%, \mathrm{n}=4)$; Colony 13 , of ferritin $(2.71 \pm 9 \%, \mathrm{n}=4)$ and $\mathrm{Zn}^{2+}$-metalloprotease $(0.65 \pm$ $9.2 \%, \mathrm{n}=4)$; Colony 15, of HSP70 $(8.9 \pm 3.3 \%, \mathrm{n}=4)$ and $\mathrm{Zn}^{2+}$-metalloprotease $(13.1 \pm 15.3 \%, \mathrm{n}=4)$; and finally Colony 19, for $\operatorname{MnSOD}(5.1 \pm 7.3 \%, \mathrm{n}=4)$ and $\mathrm{Zn}^{2+}$-metalloprotease $(11.13 \pm 5.6 \%, \mathrm{n}=4)$.

Only for MnSOD was the inter-colony variation in gene expression levels significantly higher than the intra-colony variation $(p=0.031)$. Levene's test showed heterogeneity of error variances for all genes except for $M n S O D$. Equal variances for expression rates within colonies were not assumed; thus, Tamhane's T2 post-hoc test was applied and showed no significant variation among colonies $(p>0.05)$. Only once the highly variable Colony 4 had been excluded from the ANOVA, expression levels for both HSP7O ( $\mathrm{p}=0.035)$ and $\mathrm{Zn}^{2+}$-metalloprotease $(\mathrm{p}=0.003$ ) varied significantly more between than within colonies. For changes in ferritin expression, however, the intra-colony variation constantly exceeded variation between colonies, irrespective of whether data from any of the highly varying colonies were excluded.

In addition, a 1-way ANOVA on $C_{\mathrm{t}}$ values of control samples allowed an indication as to whether intracolony variation was comparably high under control conditions (see 'Materials and methods'). Using this approximation, we found that variation in GOI expression was highly significant between coral genotypes ( $p<0.001$ for all genes except for $\mathrm{Zn}^{2+}$-metalloprotease, for which $\mathrm{p}=0.002$ ), indicating that intra-colony variation in stress gene expression levels was less variable under control conditions.

There were significant positive correlations for the expression levels between most of the genes (Table 2) across the bleached samples $(n=79)$. The highest correlations were found for $\mathrm{HSP} 70$ and both $\mathrm{Zn}^{2+}$ metalloprotease $(\mathrm{r}=0.595 ; \mathrm{p}<0.01)$ and MnSOD $(\mathrm{r}=$ 0.489; $\mathrm{p}<0.01)$. Although there was a weak tendency for ferritin and MnSOD ( $\mathrm{r}=0.144)$ to be expressed in the same direction, this trend was not significant $(\mathrm{p}>$ 0.05).

\section{DISCUSSION}

To our knowledge, the present study represents the first gene expression analysis of a scleractinian coral population exposed exclusively to thermal stress, comparing as many as 20 distinct genotypes with 4 clonal replicates. We targeted 4 host genes involved in the oxidative stress response (HSP70, MnSOD, ferritin and a $\mathrm{Zn}^{2+}$-metalloprotease) and normalised their ex- pression levels to expression levels of 2 internal control genes. All 4 genes were significantly up-regulated in the moderately bleached Acropora millepora samples relative to their non-stressed control samples, highlighting their importance in the cellular defence machinery.

However, our data demonstrate significant variation in direction and amplitude of gene expression rates both within and between the visually stressed coral colonies at a particular and common point in time. The enormous variation detected among the clonal replicates of each colony is remarkable considering that thermal stress was applied equally and under highly controlled laboratory conditions. We have shown that different coral genotypes, despite showing a general trend for up-regulation of stress genes, were not necessarily synthesising all the investigated gene products equally and at the same time (Fig. 1). In fact, some of the colonies showed virtually no expression changes in relation to control samples for genes that were, on average, down-regulated (i.e. the colonies that showed only a minimal overall down-regulation, such as Colony 8 for HSP70 and Colony 13 for $\mathrm{Zn}^{2+}$ metalloprotease). However, the fact that certain colonies did actually show down-regulation for some of the genes to varying degrees confirms that visually assessed levels of bleaching, although similar across all colonies, do not necessarily reflect similar cellular processes (sensu Fitt et al. 2000). This holds true for the transcript abundances of all genes and their resulting respective biological implications (as discussed later on) in the individual coral samples to which that might apply.

Our results stress the importance of measuring variation between genetically identical individuals (Crawford \& Oleksiak 2007), which is crucial in interpreting gene expression data in studies where generally only a single nubbin per colony is used. Inter-individual variation in gene expression among invertebrates has generally been poorly studied (Whitehead \& Crawford 2006), most likely due to the fact that many of the small individual model organisms seldom yield enough mRNA for individual comparisons; hence, samples are pooled. However, this need not be true for larger modular invertebrates such as corals; yet, many experimental designs only test for differences among treatments and either use only 1 replicate per genotype or replicate samples of pooled individuals.

Another remarkable aspect of the gene expression data is that the overall up-regulation of the 4 stress genes was low $(<50 \%$ on average), although coral samples were exposed to $32^{\circ} \mathrm{C}$ for a total of $9 \mathrm{~d}$ and visually bleached thereafter. This could be mainly due to 2 reasons. First, gene expression in corals in response to oxidative stress might be transient (discussed 
below); thus, any potentially higher levels of antioxidant gene expression at the onset of oxidative stress may have been missed. Second, dilution factors of some, if not all, genes are likely to have been introduced due to the fact that cellular levels of stress may vary between symbiotic and non-symbiotic cells (Rodriguez-Lanetty et al. 2006). The algal symbionts reside solely in the gastrodermal cells of the coral host. In the visually bleached coral samples, cellular levels of toxic oxidants might have been relatively elevated in the remaining, zooxanthella-harbouring host cells due to their combined ROS production by mitochondria and algal chloroplasts. Therefore, it is likely that larger fold changes in the reduced number of symbiotic host cells were concealed by less differential expression in the already bleached, non-symbiotic host cells. Nevertheless, the slight changes in stress gene expression reported in our study are well within the range of fold changes in stress gene expression in a recently published study on the Caribbean stony coral Montastraea faveolata (DeSalvo et al. 2008). In this respect, even apparently minor changes in gene expression are assumed to have biological importance (Crawford \& Oleksiak 2007), as has been indicated by evolutionary analysis in invertebrate and vertebrate taxa (e.g. Denver et al. 2005, Lemos et al. 2005), implying that stabilising selection on transcription levels has prevented greater changes in mRNA levels. Data on organisms as diverse as Caenorhabditis elegans (Denver et al. 2005), Drosophila sp. (Lemos et al. 2005), Fundulus heteroclitus (Crawford \& Oleksiak 2007) and humans (e.g. Gilad et al. 2005, 2006) suggest that variation in gene expression is selectively important; hence, even small variation is very likely to be biologically important.

Relevant in this regard is the observation that HSP70, although known to be among the most ubiquitous and decisive stress markers in all living cells (reviewed by Feder \& Hofmann 1999), showed a mere low relative overall up-regulation compared to 2 of the other genes. With an overall up-regulation of about $12 \%$, HSP70 expression levels across all bleached samples were well below those for MnSOD ( 20\%) and ferritin ( 24\%) (Table 2). MnSOD, one of the many coral host SOD isoforms (Richier et al. 2003) that is particularly localised to mitochondria in eukaryotic cells (Fridovich 1995), is equally well known for constituting the first line of enzymatic cellular antioxidant defence. Yet, the moderately elevated transcript abundances of these 2 recognised universal stress markers are likely to reflect realistic estimates of true expression levels, given the large representative sample size and the uniformity of experimental conditions.

The biological functions of each of the 4 investigated gene products in the present study have not yet received equal attention in the published coral literature. While the roles of HSPs and SODs in the corals' oxidative stress response are generally well described (e.g. Downs et al. 2000, 2002, Lesser 2006), the roles of ferritin and $\mathrm{Zn}^{2+}$-metalloproteases are less so. We will therefore start discussing some potential aspects of the role ferritin might play in the corals' bleaching response.

Ferritin is a highly conserved and ubiquitous ironsequestering protein (Harrison \& Arosio 1996), and one of its major functions in biological systems is to minimise $\mathrm{Fe}^{2+}$ availability for participation in generating reactive oxygen radicals (Torti et al. 1988, Halliwell \& Gutteridge 1989). Remarkably, of all the 4 genes investigated in the present study, ferritin showed the highest overall up-regulation in the bleached coral samples. It is known that ROS may release iron from ferritin as well as other cellular proteins, and the resulting elevated intra-cellular iron pools, in turn, lead to an increased synthesis of ferritin (reviewed by Torti \& Torti 2002). In contrast to vertebrates, where ferritin synthesis is under both transcriptional and translational regulation (Tsuji et al. 2000), it seems that transcriptional regulation is the primary mode of response to iron and stress-related signals in invertebrates (Torti \& Torti 2002). Ferritin mRNA levels thus approximate protein levels better than in the case of genes in which post-transcriptional regulation is likely to play a larger role. This makes the ferritin expression level in corals an especially useful indicator for the status of iron-homeostasis, as well as overall levels of oxidative stress during bleaching. In vertebrate cells exposed to oxidative stress, a sustained increase in ferritin transcription, rather than an exclusively transient change, has been reported (Tsuji et al. 2000). Our study, although not designed to confirm or rule out any potentially higher transient changes at the onset of stress, demonstrates a sustained up-regulation of ferritin in corals after an extended period of applied thermal stress. Our results thus suggest a sustained unstable intra-cellular iron household in corals facing bleaching conditions.

The second class of stress-related markers that has received little attention in coral literature belong to the matrix metalloproteases (MMPs), a family of over 20 enzymes characterised by their ability to degrade the extra-cellular matrix (ECM) and their dependence on $\mathrm{Zn}^{2+}$ binding for proteolytic activity. Coordinated regulation of these metalloproteases governs the cleavage and release of many important growth factors and cellsurface receptors, and thus many biological aspects ranging from cell proliferation and migration, to differentiation and remodelling of the ECM (Chang \& Werb 2001). The specific $\mathrm{Zn}^{2+}$-metalloprotease, whose expression level we assessed in our study, showed the 
lowest overall up-regulation relative to the other 3 distinct genes. This is not surprising, however, given the functional diversity of the MMP family, and the fact that many of them are usually up-regulated at any one time to orchestrate their multiple biological tasks (Chang \& Werb 2001). In the living coral samples, it is thus likely that multiple $\mathrm{Zn}^{2+}$-metalloproteases were either sequentially and/or continuously synthesised during their chronic exposure to bleaching conditions (i.e. $9 \mathrm{~d}$ at $32^{\circ} \mathrm{C}$ ). Our data suggest at the transcriptional level the already phenotypically observed dysfunction of coral cell-adhesion proteins during bleaching (Gates et al. 1992) via a remodelling of the ECM.

Finally, the significant positive correlation of gene expression between almost all combinations of the 4 genes studied indicates the importance and context dependency of gene expression in thermally stressed and bleached corals. In summary, these 4 genes represent only a snapshot of the corals' dynamic transcriptome; yet, expression levels of the investigated sub-set within this population display enormous variation at a single and common time point during bleaching conditions, both at the inter- and intra-colony level, thus highlighting the importance of measuring individual variation in the molecular stress response.

Acknowledgements. We thank P. J. Ralph for advice and general support, and R. Berkelmans for providing support and the temperature-control room facilities. This project was funded by the Australian Government's Marine and Tropical Sciences Research Facility and the Australian Institute of Marine Science. N.B.M.C. acknowledges receipt of an International Postgraduate Research Scholarship from the University of Technology, Sydney, as well as an award from the Australian Coral Reef Society.

\section{LITERATURE CITED}

Balla G, Jacob HS, Balla J, Rosenberg M and others (1992) Ferritin: a cytoprotective antioxidant strategem of endothelium. J Biol Chem 267:18148-18153

Benjamin IJ, McMillan DR (1998) Stress (heat shock) proteins: molecular chaperones in cardiovascular biology and disease. Circ Res 83:117-132

Brown BE, Dunne RP, Goodson MS, Douglas AE (2000) Experience shapes the susceptibility of a reef to coral bleaching. Coral Reefs 21:119-126

Brown BE, Downs CA, Dunne RP, Gibb SW (2002) Exploring the basis of thermotolerance in the reef coral Goniastrea aspera. Mar Ecol Prog Ser 242:119-129

Bustin SA (2004) A-Z of quantitative PCR. IUL Press, San Diego, CA

Cairo G, Tacchini L, Pogliaghi G, Anzon E, Tomasi A, Bernelli-Zazzera A (1995) Induction of ferritin synthesis by oxidative stress. Transcriptional and post-transcriptional regulation by expansion of the 'free' iron pool. J Biol Chem 270:700-703

Chang C, Werb Z (2001) The many faces of metalloproteases: cell growth, invasion, angiogenesis and metastasis. Trends Cell Biol 11:S37-S43
Crawford DL, Oleksiak MF (2007) The biological importance of measuring individual variation. J Exp Biol 210: 1613-1621

D'Aoust BG, White R, Wells JM, Olsen DA (1976) Coral-algal associations: capacity for producing and sustaining elevated oxygen tensions in situ. Undersea Biomed Res 3: 35-40

$>$ Dalton TP, Shertzer HG, Puga A (1999) Regulation of gene expression by reactive oxygen. Annu Rev Pharmacol Toxicol 39:67-101

Denver DR, Morris K, Streelman JT, Kim SK, Lynch M, Thomas WK (2005) The transcriptional consequences of mutation and natural selection in Caenorhabditis elegans. Nat Genet 37:544-548

> DeSalvo MK, Voolstra CR, Sunagawa S, Schwarz JA and others (2008) Differential gene expression during thermal stress and bleaching in the Caribbean coral Montastrea faveolata. Mol Ecol 17:3952-3971

Donner SD, Skirving WJ, Little CM, Oppenheimer M, HoeghGuldberg O (2005) Global assessment of coral bleaching and required rates of adaptation under climate change. Glob Change Biol 11:2251-2265

> Douglas AE (2003) Coral bleaching how and why? Mar Pollut Bull 46:385-392

Downs CA, Mueller E, Phillips S, Fauth JE, Woodley CM (2000) A molecular biomarker system for assessing the health of coral (Montastraea faveolata) during heat stress. Mar Biotechnol 2:533-544

Downs CA, Fauth JE, Halas JC, Dustan P, Bemiss J, Woodley CM (2002) Oxidative stress and seasonal coral bleaching. Free Radic Biol Med 33:533-543

> Edge SE, Morgan MB, Gleason DF, Snell TW (2005) Development of a coral cDNA array to examine gene expression profiles in Montastraea faveolata exposed to environmental stress. Mar Pollut Bull 51:507-523

Edge SE, Morgan MB, Snell TW (2008) Temporal analysis of gene expression in a field population of the scleractinian coral Montastraea faveolata. J Exp Mar Biol Ecol 355: $114-124$

> Feder ME, Hofmann GE (1999) Heat-shock proteins, molecular chaperones, and the stress response: evolutionary and ecological physiology. Annu Rev Physiol 61:243-282

Fitt WK, McFarland FK, Warner ME, Chilcoat GC (2000) Seasonal patterns of tissue biomass and densities of symbiotic dinoflagellates in reef corals and relation to coral bleaching. Limnol Oceanogr 45:677-685

Fridovich I (1995) Superoxide radical and superoxide dismutases. Annu Rev Biochem 64:97-112

> Fridovich I (1998) Oxygen toxicity: a radical explanation. J Exp Biol 201:1203-1209

> Gasch AP, Spellman PT, Kao CM, Carmel-Harel O and others (2000) Genomic expression programs in the response of yeast cells to environmental changes. Mol Biol Cell 11: 4241-4257

> Gates RD, Baghdasarian G, Muscatine L (1992) Temperature stress causes host cell detachment in symbiotic cnidarians: implications for coral bleaching. Biol Bull 182:324-332

> Gething MJ, Sambrook J (1992) Protein folding in the cell. Nature 355:33-45

> Gilad Y, Rifkin SA, Bertone P, Gerstein M, White KP (2005) Multi-species microarrays reveal the effect of sequence divergence on gene expression profiles. Genome Res 15:674-680

Gilad Y, Oshlack A, Smyth GK, Speed TP, White KP (2006) Expression profiling in primates reveals a rapid evolution of human transcription factors. Nature 440:242-245

> Gleason DF, Wellington GM (1993) Ultraviolet radiation and coral bleaching. Nature 365:836-838 
Glynn PW (1996) Coral reef bleaching: facts, hypotheses and implications. Glob Change Biol 2:495-509

Halliwell B, Gutteridge JM (1989) Protection against oxidants in biological systems: the superoxide theory of oxygen toxicity. In: Halliwell B, Gutteridge JM (eds) Free radicals in biology and medicine. Clarendon Press, Oxford, p 86-179

$>$ Harrison PM, Arosio P (1996) The ferritins' molecular properties, iron storage function and cellular regulation. Biochim Biophys Acta 1275:161-203

Hoegh-Guldberg O (1999) Climate change, coral bleaching and the future of the world's coral reefs. Mar Freshw Res 50:839-866

Hughes TP, Baird AH, Bellwood DR, Card M and others (2003) Climate change, human impacts, and the resilience of coral reefs. Science 301:929-933

> Jones RJ, Hoegh-Guldberg O, Larkum AWD, Schreiber U (1998) Temperature-induced bleaching of corals begins with impairment of the $\mathrm{CO}_{2}$ fixation mechanism in zooxanthellae. Plant Cell Environ 21:1219-1230

Lemos B, Meiklejohn CD, Ceres MC, Hartl DL (2005) Rates of divergence in gene expression profiles of primates, mice, and flies: stabilizing selection and variability among functional categories. Evolution 59:126-137

Lesser MP (2006) Oxidative stress in marine environments: biochemistry and physiological ecology. Annu Rev Physiol 68:253-278

Madamanchi NR, Li S, Patterson C, Runge MS (2001) Reactive oxygen species regulate heat-shock protein 70 via the JAK/STAT pathway. Arterioscler Thromb Vasc Biol 21: 321-326

Mieog JC, van Oppen MJH, Berkelmans R, Stam WT, Olsen JL (2009) Quantification of algal endosymbionts (Symbiodinium) in coral tissue using real-time PCR. Mol Ecol Resour 9:74-82

Morgan MB, Snell TW (2002) Characterizing stress gene expression in reef-building corals exposed to the mosquitoside dibrom. Mar Pollut Bull 44:1206-1218

- Morgan MB, Vogelien DL, Snell TW (2001) Assessing coral stress responses using molecular biomarkers of gene transcription. Environ Toxicol Chem 20:537-543

> Morgan MB, Edge SE, Snell TW (2005) Profiling differential gene expression of corals along a transect of waters adjacent to the Bermuda municipal dump. Mar Pollut Bull 51:524-533

- Orita M, Suzuki Y, Sekiya T, Hayashi K (1989) Rapid and sensitive detection of point mutation and DNA polymorphisms using polymerase chain reaction. Genomics 5: 874-879

Richier S, Merle PL, Furla P, Pigozzi D, Sola F, Allemand D (2003) Characterization of superoxide dismutases in anoxia- and hyperoxia-tolerant symbiotic cnidarians. Biochim Biophys Acta 1621:84-91

Richier S, Furla P, Plantivaux A, Merle PL, Allemand D (2005) Symbiosis-induced adaptation to oxidative stress. J Exp Biol 208:277-285

Editorial responsibility: Philippe Borsa,

Nouméa, New Caledonia
Rodriguez-Lanetty M, Phillips W, Weis VM (2006) Transcriptome analysis of a cnidarian - dinoflagellate mutualism reveals complex modulation of host gene expression. BMC Genomics 7:23-33

Scandalios JG (2002) Oxidative stress responses - What have genome-scale studies taught us? Genome Biol 3:1019.11019.6

Seneca FO, Foret S, Ball EE, Smith-Keune C, Miller DJ, van Oppen MJH (in press) Patterns of gene expression in a scleractinian coral undergoing natural bleaching. Mar Biotechnol

Snell TW, Brogdon SE, Morgan MB (2003) Gene expression profiling in ecotoxicology. Ecotoxicology 12:475-483

Sunnucks P, Wilson ACC, Beheregaray LB, Zenger K, French J, Taylor AC (2000) SSCP is not so difficult: the application and utility of single-stranded conformation polymorphism in evolutionary biology and molecular ecology. Mol Ecol 9:1699-1710

Takahashi S, Murata N (2008) How do environmental stresses accelerate photoinhibition? Trends Plant Sci 13:178-182

Torti FM, Torti SV (2002) Regulation of ferritin genes and protein. Blood 99:3505-3516

> Torti SV, Kwak EL, Miller SC, Miller LL and others (1988) The molecular cloning and characterization of murine ferritin heavy chain, a tumor necrosis factor-inducible gene. J Biol Chem 263:12638-12644

Tsuji Y, Ayaki H, Whitman SP, Morrow CS, Torti SV, Torti FM (2000) Coordinate transcriptional and translational regulation of ferritin in response to oxidative stress. Mol Cell Biol 20:5818-5827

Vandesompele J, De Preter K, Pattyn F, Poppe B, Van Roy N, De Paepe A, Speleman F (2002) Accurate normalisation of real-time quantitative RT-PCR data by geometric averaging of multiple internal control genes. Genome Biol 3: 0034.1-0034.11

van Oppen MJH, Palstra FP, Piquet AMT, Miller DJ (2001) Patterns of coral-dinoflagellate associations in Acropora: significance of local availability and physiology of Symbiodinium strains and host-symbiont selectivity. Proc R Soc Lond B Biol Sci 268:1759-1767

> van Oppen MJH, Underwood JN, Muirhead AN, Peplow L (2006) Ten microsatellite loci for the reef-building coral Acropora millepora (Cnidaria, Scleractinia) from the Great Barrier Reef, Australia. Mol Ecol Notes 7:436-438

> Warner ME, Fitt WK, Schmidt GW (1996) The effects of elevated temperature on the photosynthetic efficiency of zooxanthellae in hospite from four different species of reef coral: a novel approach. Plant Cell Environ 19: 291-299

Warner ME, Fitt WK, Schmidt GW (1999) Damage to photosystem II in symbiotic dinoflagellates: a determinant of coral bleaching. Proc Natl Acad Sci USA 96:8007-8012

Whitehead A, Crawford DL (2006) Variation within and among species in gene expression: raw material for evolution. Mol Ecol 15:1197-1211

Submitted: February 11, 2009; Accepted: July 3, 2009

Proofs received from author(s): October 13, 2009 